\title{
Effect of organic and mineral amendments upon soil respiration and microbial biomass in a saline-sodic soil
}

\author{
José E. Celis ${ }^{1}$, Marco Sandoval ${ }^{2}$, Bárbara Martínez, and Celerino Quezada ${ }^{2}$ \\ ${ }^{1}$ Facultad de Ciencias Veterinarias. ${ }^{2}$ Facultad de Agronomía, Universidad de Concepción, Vicente Méndez \\ 595, Chillán, Chile.
}

\begin{abstract}
J.E. Celis, M. Sandoval, B. Martínez, and C. Quezada. 2013. Effect of organic and mineral amendments upon soil respiration and microbial biomass in a saline-sodic soil. Cien. Inv. Agr. 40(3): 571-580. An understanding of soil carbon stocks and fluxes in saline-sodic soils is becoming critical in environmental management because salinity and sodicity are predicted to increase worldwide. The effects of amendment with sewage sludge (SW), mined gypsum (MG) and synthetic gypsum (SG) on the soil respiration rate and soil (S) microbial biomass (SMB) of a saline-sodic soil were assessed in vitro over 60 days under controlled conditions. The treatments were: $\mathrm{T} 1=\mathrm{S}+\mathrm{MG}\left(7 \mathrm{tha}^{-1}\right) ; \mathrm{T} 2=\mathrm{S}+\mathrm{MG}\left(7 \mathrm{tha}^{-1}\right)+\mathrm{SW}\left(90 \mathrm{t} \mathrm{ha}^{-1}\right) ; \mathrm{T} 3=$ $\mathrm{S}+\mathrm{SG}\left(7 \mathrm{t} \mathrm{ha}^{-1}\right) ; \mathrm{T} 4=\mathrm{S}+\mathrm{SG}\left(7 \mathrm{tha}^{-1}\right)+\mathrm{SW}\left(90 \mathrm{tha}^{-1}\right) ; \mathrm{T} 5=\mathrm{S}+\mathrm{SW}\left(90 \mathrm{tha}^{-1}\right) ; \mathrm{T} 6=\mathrm{S}+$ $\mathrm{SW}\left(270 \mathrm{t} \mathrm{ha}^{-1}\right)$; $\mathrm{T} 0=\mathrm{Control}$ (unamended soil). Soil respiration rates were determined by a respirometry method in a closed incubation chamber. SMB was measured by the chloroform fumigation-extraction procedure. The results showed that the highest respiration rate occurred when soil was amended with T6, followed by T5. Microbial respiration was the lowest with $\mathrm{T} 1$ and T3. The gypsum amendments did not significantly increase soil respiration, due to low organic matter $(\mathrm{OM})$ intake. All treatments showed a gradual decrease of SMB over the 60-day incubation period. The saline-sodic soil was able to respond positively to large amounts of added sewage sludge, up to $270 \mathrm{tha}^{-1}$.
\end{abstract}

Key words: Arid soil, biological activity, gypsum, organic matter, sewage sludge, soil respiration.

\section{Introduction}

Soil erosion, nutrient loss, accumulation of salts and toxicants, waterlogging and desertification are all contributing to soil degradation in most developing countries (Yunlong and Smit, 1994). Soil salinity and sodicity are serious issues worldwide, and unless some strong measures can be applied in order to

Received May 22, 2013. Accepted October 28, 2013. Corresponding author: jcelis@udec.cl protect lands, the area of affected soils is predicted to increase dramatically in the future (Wong et al., 2008). Globally, there are approximately 76 million hectares of saline soils (Bell, 1999) and more than 700 million hectares of sodic soils (Fekete and Fehe, 2000). Additionally, approximately $25 \%$ of all irrigated land has been affected by salts (Arshad, 2008). Human-induced salinization is the primary contributor to desertification processes in the drylands of the world (Thomas and Middleton, 1993). Desertification has progressed rapidly in 
the northern region of Chile, where approximately 34,000 hectares are affected by salinization (Santibáñez and García, 2000). Salt concentration in the surface or near-surface zones of soils contributes to land degradation and the loss of land for production in a range of environments, leading to falling crop yields (López-Aguirre et al., 2007). Salinity and sodicity especially occur where salts dominated by $\mathrm{Na}^{+}$accumulate in the soil profile (Vukadinovic and Rengel, 2007). Some evidence indicates that is possible to reclaim soil by adding various organic wastes or mineral materials, such as gypsum. However, it is necessary to understand the cycling dynamics of these materials into soil. One way to quantify their applicability is through microbial activity.

High salt content affects the physical, chemical and microbiological properties of soil. Increased $\mathrm{Na}^{+}$concentration in the soil exchange complex leads to deterioration of the soil structure, reducing soil permeability and affecting salt displacement processes (Kochba et al., 2004). There is some evidence showing that increases in salinity clearly decrease soil respiration rates, which negatively affect the decomposition of OM and the release of nutrients required to sustain productivity (Pathak and Rao, 1998; Wong et al., 2008; Shah and Shah, 2011). The reduced activity of microorganisms with increasing salinity is most likely caused by osmotic stress, as a consequence of large concentrations of salts in soil solutions (Oren, 1999). Generally, osmotic stress limits microbial growth and activity in saline soil, whereas microbial growth may be limited by ion toxicities and adverse $\mathrm{pH}$ conditions in sodic soils (Rietz and Haynes, 2003). In saline soils, specific ion toxicities from $\mathrm{Na}$ and $\mathrm{Cl}$ may also inhibit microbial growth (Zahran, 1997).

Gypsum is calcium sulfate dihydrate $\left(\mathrm{CaSO}_{4}\right.$ - $2 \mathrm{H}_{2} \mathrm{O}$ ), which comes from various sources. Gypsum is a common mineral found around the world in sedimentary rock formations, from which it is mined or quarried (Clark et al., 1999). Flue gas desulphurization gypsum is a synthetic material of identical chemical structure produced as a byproduct from coal-fired electric utilities (DeSutter and Cihacekm, 2009). Both mined and synthetic gypsum can be used as a soil amendment in a range of soils (Fekete and Feher, 2000; Aydemir and Najjar, 2005). Gypsum can be used as mineral amendment to improve soil physical and chemical properties (Clark et al., 1999). Gypsum amendments effectively increase $\mathrm{Ca}^{2+}$ concentration in the soil solution, thus decreasing $\mathrm{Na}^{+}$ concentration (Vukadinovic and Rengel, 2007).

Adding OM to soil may also help to exchange adsorbed $\mathrm{Na}^{+}$with $\mathrm{Ca}^{2+}$ and to displace $\mathrm{Na}^{+}$, thus reducing salinity (Avnimelech et al., 1994). Additionally, some evidence suggests that sewage sludge amendments improve the activity of microorganisms in arid soils, implying that adding organic wastes might be a suitable technique to restore soil quality (Pascual et al., 1999). Mixing organic wastes with gypsum increases the solubility of gypsum through the action of chelating ligands present in the organic material or its decomposition products, and amendment with such mixtures may improve soil structure (Kochba et al., 2004). High levels of soil OM are always associated with liberal amounts of calcium, which is a component of gypsum (Aydemir and Najjar, 2005). As a consequence, blends of gypsum and organics increase the value of the organic amendments, especially for soil structure improvement. The role of $\mathrm{Ca}$ in clay and soil OM flocculation possibly involves the bridging of clay aggregates to organic materials (Muneer and Oades, 1989).

Some studies using different organic amendments on degraded soils have shown a positive effect on microbial respiration as the dose increased from 15 to 150 t ha $^{-1}$ (Celis et al., 2009; Celis et al., 2011). According to Banerjee et al. (1997), the application of different amounts of sludge significantly increases the amount of SMB. However, some studies performed in saline and sodic soils show contradictory results. Soil respiration and SMB were negatively correlated with salinity as increased substrate C is mineralized for cell maintenance (Muhammad et al., 2008; Tripathi et al., 2006). Another study 
found that SMB increased positively with salinity, while soil respiration and the metabolic quotient $\left(\mathrm{M}_{\mathrm{t}} \mathrm{C}\right)$ increased as the salinity decreased (Wong et al., 2008). Microbial activity, expressed as $\mathrm{CO}_{2}$ evolution, depends on the labile $\mathrm{C}$ pool, defined as soil organic carbon (SOC) with a turnover time on the order of weeks (Parton et al., 1987). To determine stress in the microbial population, the $\mathrm{M}_{\mathrm{t}} \mathrm{C}$ is frequently used and measures the ratio of respiration to the SMB (Anderson and Domsch, 1993). The $M_{b} C$ is the ratio of the SMB to SOC and indicates the substrate availability. Its value increases as available organic $\mathrm{C}$ input increases, and its value decreases when the $\mathrm{C}$ input decreases (Anderson and Domsch, 1989).

Chilean environmental regulations are becoming stricter to protect soils, especially when large amount of wastes amended to soil need to be completely controlled. Therefore, it is necessary to understand the dynamics of $\mathrm{OM}$ decomposition to design sustainable practices. Unfortunately, few studies have examined the effects of sewage sludge mixed with gypsum amended to saline-sodic soils, and fewer have investigated the impact of such amendments on microbial activity (Nelson et al., 1997; Rietz and Haynes, 2003). In particular, little is known about how those amendments influence the respiration rate and SMB of Chilean arid soils. Consequently, the aim of this study was to assess the effect of sewage sludge and gypsums on soil $\mathrm{C}$ dynamics as indicated by the microbial activity (respiration rate) and SMB. We examined the effects of different doses of sewage sludge and gypsums in a saline-sodic soil under controlled temperature and moisture conditions.

\section{Materials and methods}

\section{Samples}

Soil samples $(0-20 \mathrm{~cm})$ used in the laboratory were obtained from a sector at Copiapó $\left(27^{\circ} 18^{\prime} \mathrm{S}\right.$; $\left.70^{\circ} 25^{\prime} \mathrm{W}\right)$, Atacama region, Chile. Municipal sewage sludge was collected from an activated sludge reactor at the wastewater treatment plant of the city of Chillán $\left(36^{\circ} 36^{\prime} \mathrm{S}, 72^{\circ} 07^{\prime} \mathrm{W}\right)$. Mined gypsum was obtained from the local market, and synthetic gypsum from a coal-power plant located in the Atacama region. The physicochemical properties of the soil are given in Table 1, and those for sewage sludge and gypsums are provided in Table 2. The chemical properties of the mined gypsum and synthetic gypsum were very similar.

Table 1. Physicochemical properties of the saline-sodic soil used in the experiment (mean values \pm standard deviation).

\begin{tabular}{lcc}
\hline Property & Unit & Value \\
\hline $\mathrm{pH}_{\mathrm{s}}$ & - & $8.4 \pm 1.1$ \\
$\mathrm{pH}_{2}$ & - & $8.1 \pm 0.9$ \\
$\mathrm{ECe}$ & $\mathrm{dS} \mathrm{m}^{-1}$ & $102.6 \pm 8.5$ \\
$\mathrm{CEC}$ & ${\mathrm{cmol}(+) \mathrm{kg}^{-1}}^{-}$ & $5.89 \pm 1.4$ \\
Organic C & $\%$ & $0.02 \pm 0.01$ \\
Exchangeable sodium & $\%$ & $75.47 \pm 2.8$ \\
percent (EPS) & & \\
Bulk density & $\mathrm{g} \mathrm{cm}^{-3}$ & $0.80 \pm 0.2$ \\
$\mathrm{NO}_{3}$-N & $\mu \mathrm{g} \mathrm{kg}^{-1}$ & $13.4 \pm 1.5$ \\
Olsen-P & $\mu \mathrm{g} \mathrm{kg}^{-1}$ & $15.6 \pm 1.7$ \\
Total N & $\%$ & $0.07 \pm 0.03$ \\
\hline
\end{tabular}

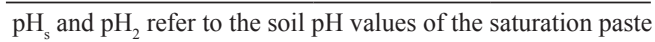
and $1: 2$ soil-water suspension, respectively.

All samples were slowly air-dried and ground $(<2$ $\mathrm{mm})$. Soil $\mathrm{pH}$ and ECe (electrical conductivity) were measured in saturation paste and extract, respectively, as well as in 1:2 soil-water suspensions. The physical and chemical characterizations of all samples were performed at the laboratories of the Departamento de Suelos y Recursos Naturales of the Universidad de Concepción (certified by the Chilean Soil Science Society since 2000). All samples were maintained at temperatures below $10^{\circ} \mathrm{C}$ before processing.

\section{Treatments}

Different amounts of sewage sludge (SW), mined gypsum (MG) and synthetic gypsum (SG) based on $1 \mathrm{~kg}$ of saline-sodic soil (S) each were prepared. Treatments were as follows: $\mathrm{T} 1=\mathrm{S}+\mathrm{MG}(7 \mathrm{t}$ $\left.\mathrm{ha}^{-1}\right) ; \mathrm{T} 2=\mathrm{S}+\mathrm{MG}\left(7 \mathrm{t} \mathrm{ha}^{-1}\right)+\mathrm{SW}\left(90 \mathrm{tha}^{-1}\right)$; 
Table 2. Physicochemical properties of the sewage sludge (SW), mined gypsum (MG) and synthetic gypsum (SG) used in the experiment (mean values \pm standard deviation).

\begin{tabular}{lcccc}
\hline Parameter & Unit & $\mathrm{SW}$ & $\mathrm{MG}$ & SG \\
\hline $\mathrm{pH}$ (water) & - & $5.94 \pm 1.0$ & - & - \\
Organic matter $(\mathrm{OM})$ & $\%$ & $41.95 \pm 5.4$ & - & - \\
$\mathrm{NO}_{3}-\mathrm{N}$ & $\mathrm{mg} \mathrm{kg}^{-1}$ & $17.1 \pm 2.1$ & - & - \\
$\mathrm{NH}_{4}-\mathrm{N}$ & $\mathrm{mg} \mathrm{kg}^{-1}$ & $424.0 \pm 10.9$ & - & - \\
Olsen-P & $\mathrm{mg} \mathrm{kg}^{-1}$ & $853.2 \pm 15.6$ & - & - \\
$\mathrm{K}$ available & $\mathrm{mg} \mathrm{kg}^{-1}$ & $5,591.0 \pm 43.2$ & - & - \\
$\mathrm{Water}$ & $\%$ & - & $0.10 \pm 0.07$ & $0.15 \pm 0.09$ \\
$\mathrm{CaSO}_{4} \times 2 \mathrm{H}_{2} \mathrm{O}$ & $\%$ & - & $80.0 \pm 4.2$ & $75 \pm 8.7$ \\
$\mathrm{CaCO}_{3}$ & $\%$ & - & $9.6 \pm 1.4$ & $8.7 \pm 1.1$ \\
$\mathrm{NaCl}$ & $\%$ & - & $0.04 \pm 0.02$ & $0.03 \pm 0.01$ \\
$\mathrm{MgCO}_{3}$ & $\%$ & - & $0.11 \pm 0.06$ & $0.12 \pm 0.07$ \\
$\mathrm{FeO}_{3}+\mathrm{Al}_{2} \mathrm{O}_{3}$ & $\%$ & - & $0.20 \pm 0.08$ & $0.30 \pm 0.06$ \\
\hline
\end{tabular}

$\mathrm{T} 3=\mathrm{S}+\mathrm{SG}\left(7 \mathrm{tha} \mathrm{a}^{-1}\right) ; \mathrm{T} 4=\mathrm{S}+\mathrm{SG}\left(7 \mathrm{tha^{-1 }}\right)+$ $\mathrm{SW}\left(90 \mathrm{t} \mathrm{ha}^{-1}\right) ; \mathrm{T} 5=\mathrm{S}+\mathrm{SW}\left(90 \mathrm{t} \mathrm{ha}^{-1}\right) ; \mathrm{T} 6=\mathrm{S}+$ SW (270 t ha $\left.{ }^{-1}\right) ;$ T0 $=$ Control (unamended soil). Treatments were set up as totally organic (T5 and T6), totally mineral (T1 and T3), and an organic/ mineral mixture (T2 and T4). All treatments were homogenized, packaged in plastic bags, and then placed in a chamber (with temperature and humidity automatically controlled at $25^{\circ} \mathrm{C}$ and $60-70 \%$, respectively) for a 10 -day pre-incubation period.

\section{Respiration rate}

For the incubation process itself, samples consisting of $25 \mathrm{~g}$ of the amended and control soils were placed (in triplicate) in glass jars $(1 \mathrm{~L})$. Then, a test tube with $15 \mathrm{~mL}$ of a $0.05 \mathrm{M} \mathrm{NaOH}$ solution and a tube with deionized water were placed in each jar to absorb the $\mathrm{CO}_{2}$ produced by microorganisms and to keep the humidity constant, respectively. Then, each bottle was sealed hermetically. The bottles were placed in an incubation chamber at $22^{\circ} \mathrm{C}$ for 60 days. Measurements of non-neutralized $\mathrm{NaOH}$ over time were accomplished by titration $(0.1 \mathrm{M} \mathrm{HCl})$. Then, $1 \mathrm{~mL}$ of $\mathrm{NaOH}$ was extracted (in duplicate), and $2 \mathrm{~mL}$ of $\mathrm{BaCl}_{2}(0.5 \mathrm{M})$ was added to precipitate the inorganic $\mathrm{C}$ as insoluble $\mathrm{BaCO}_{3}$. Drops of phenolphthalein were added as an acid-base indicator, so that the non-neutralized $\mathrm{NaOH}$ was titrated directly with $\mathrm{HCl}$ (Ianotti et al., 1994). The amount of $\mathrm{CO}_{2}-\mathrm{C}$ generated from the incubated mixtures was calculated according to the formula suggested by Anderson (1982) as modified below:

$$
R_{\text {rat }}=\frac{45 \times(B-V) \times N \times 1000}{S_{g} \times(1-h)}
$$

where $\mathrm{R}_{\text {rat }}$ is the respiration rate $\left(\mu \mathrm{g} \mathrm{CO}_{2}-\mathrm{C} \mathrm{g}^{-1}\right)$, $\mathrm{B}$ is the volume of $\mathrm{HCl}$ used in the titration of $\mathrm{NaOH}$ in the blank (mL), $\mathrm{V}$ is the volume of $\mathrm{HCl}$ used in the titration of $\mathrm{NaOH}$ from the amended soil ( $\mathrm{mL}), \mathrm{N}$ is the $\mathrm{HCl}$ normality, $\mathrm{S}_{\mathrm{g}}$ is the amount of soil incubated (g), and $\mathrm{h}$ is the humidity (as decimal) of the incubated soil.

\section{Soil microbial biomass}

SMB was measured by the chloroform fumigation-extraction procedure described in Vance et al. (1987). There was a negligible effect on dichromate oxidation by $\mathrm{Cl}^{-}$interference following calculation of the $\mathrm{Cl}^{-}$correction factor. All analyses were performed in triplicate. The metabolic quotient, $\mathrm{M}_{\mathrm{t}} \mathrm{C}$, and microbial quotient, 
$\mathrm{M}_{\mathrm{b}} \mathrm{C}$, were determined at the end of the 60-day incubation period as follows:

$M_{t} C=\frac{R_{r a t}}{S M B}$

$M_{b} C=\frac{S M B}{S O C}$

where $\mathrm{R}_{\text {rat }}$ is the respiration rate $\left(\mu \mathrm{g} \mathrm{CO}_{2}-\mathrm{C} \mathrm{g}^{-1}\right)$, $\mathrm{SMB}$ is the soil microbial biomass $\left(\mu \mathrm{g} \mathrm{g} \mathrm{g}^{-1}\right)$, and $\mathrm{SOC}$ is the soil organic carbon $\left(\mu \mathrm{g} \mathrm{C} \mathrm{g}^{-1}\right)$.

\section{Statistical analysis}

Results obtained from in vitro respirometry trials were expressed as $\mu \mathrm{g} \mathrm{CO}_{2}-\mathrm{C} \mathrm{g}^{-1}$ soil (dry matter basis, oven at $105^{\circ} \mathrm{C}$ x $24 \mathrm{~h}$ ). Mean values for each sampling time were used. Data were normalized using the expression $(\mathrm{x}+0.5)^{0.5}$ and then processed by means of ANOVA, and the comparison among means was performed using Tukey's tests. In all cases, the level of significance used was $95 \%$ $(\mathrm{P} \leq 0.05)$. The values were processed using SAS statistical software (SAS Institute Inc, Cary, NC, USA).

\section{Results and discussion}

Figure 1 shows the $\mathrm{CO}_{2}-\mathrm{C}$ evolution in the salinesodic soil when amended with different doses of sewage sludge and gypsums. In general, a non-linear increasing trend of microbial activity with time was observed, similar to other studies performed in a degraded arid soil amended with urban wastes (Ros et al., 2003), a Patagonian soil amended with salmon sludge (Celis et al., 2009), and a degraded granitic soil amended with salmon sludge (Celis et al., 2011). The control followed a similar trend until the first 20 days of incubation and then decreased. This pattern may be explained as a consequence of microorganisms

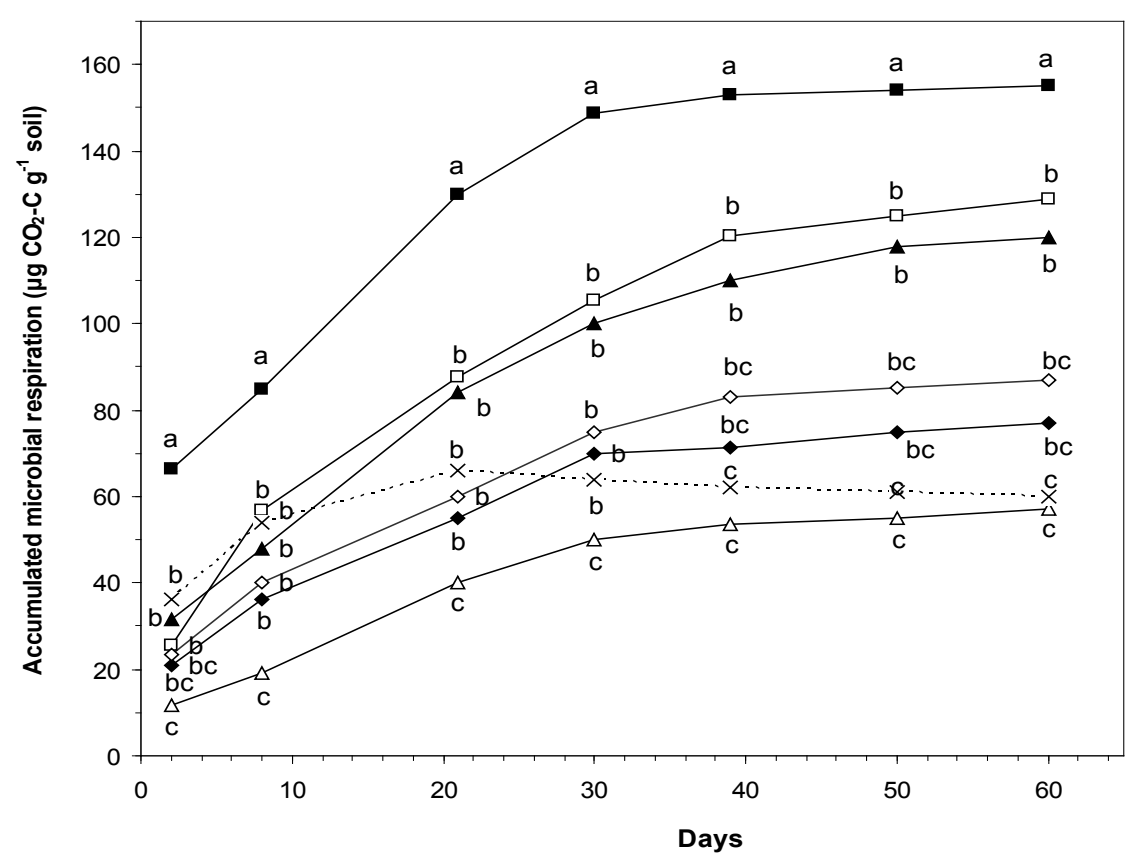

Figure 1. $\mathrm{CO}_{2}-\mathrm{C}$ evolution over the 60 -day incubation period from a saline-sodic soil (S) under different amendments with sewage sludge (SW), mined gypsum (MG) and synthetic gypsum (SG). T1 $(\Delta)=\mathrm{S}+$ MG $\left(7 \mathrm{t} \mathrm{ha}^{-1}\right) ; \mathrm{T} 2(\square)=\mathrm{S}+\mathrm{Mr}\left(7 \mathrm{t} \mathrm{ha}^{-1}\right)+\mathrm{SW}\left(90 \mathrm{t} \mathrm{ha}^{-1}\right) ; \mathrm{T} 3(\bullet)=\mathrm{S}+\mathrm{SG}\left(7 \mathrm{t} \mathrm{ha}^{-1}\right) ; \mathrm{T} 4(\diamond)=\mathrm{S}+\mathrm{SG}$ $\left(7 \mathrm{tha}^{-1}\right)+\mathrm{SW}\left(90 \mathrm{t} \mathrm{ha}^{-1}\right) ; \mathrm{T} 5(\boldsymbol{\Delta})=\mathrm{S}+\mathrm{SW}\left(90 \mathrm{tha}^{-1}\right) ; \mathrm{T} 6(\boldsymbol{\square})=\mathrm{S}+\mathrm{SW}\left(270 \mathrm{tha}^{-1}\right) ; \mathrm{T} 0(\mathrm{X})=\mathrm{Control}$ (unamended soil). Different letters by the same day indicates a significant difference $(\mathrm{P} \leq 0.05)$. 
having rapidly depleted the low level of organic $\mathrm{C}$ in the saline-sodic soil $(0.02 \%$, Table 1$)$.

There was more $\mathrm{CO}_{2}$ evolution as the amount of OM added to soil increased. Sewage sludge amendments at $270 \mathrm{t} \mathrm{ha}^{-1}$ (T6) notably produced more $\mathrm{CO}_{2}-\mathrm{C}$ than other treatments $(\mathrm{P} \leq 0.05)$ during the whole incubation period. It is possible that sewage sludge became available in treatments T5 and T6 due to the controlled soil moisture content during the experiment. This could result in increased respiratory activity of the microbial population, with the highest rates of respiration occurring in the high-sewage-sludge treatment. The rest of the treatments showed levels of $\mathrm{CO}_{2}-\mathrm{C}$ production not significantly higher than those of the control (T0), with the exception of mined gypsum amendments (T1), which showed the lowest $(\mathrm{P} \leq 0.05)$ microbial respiration rate. Water-soluble $\mathrm{C}$ can provide a large proportion of the substrate, which is immediately available and has the potential to be replenished rapidly by the continued dissolution of OM (Jandl and Sollins, 1997).

After 60 days of incubation, soil treated with sewage sludge at $270 \mathrm{t} \mathrm{ha}^{-1}$ (T6) accumulated significantly more $\mathrm{CO}_{2}-\mathrm{C}$ than all of the other treatments. These highest $\mathrm{CO}_{2}-\mathrm{C}$ values reflected greater $\mathrm{C}$ and energy availability for soil heterotrophic microorganisms as a consequence of an abundant provision of $\mathrm{OM}$ and $\mathrm{N}$, thus stimulating microbial activity (Zagal et al., 2002; Ros et al., 2003). According to Jünemann (1969), as cited by Esparza et al. (2004), soils with low OM content, such as the saline-sodic soil investigated, respond positively to sludge addition. The addition of organic wastes stimulates microbial growth, increasing OM decomposition (Barrena et al., 2006). For that reason, chemical amendments with gypsums showed lower $\mathrm{CO}_{2}-\mathrm{C}$ values than organic amendments with sewage sludge. Evolution of $\mathrm{CO}_{2}-\mathrm{C}$ due to large sewage sludge addition to saline-sodic soil suggests a positive effect on

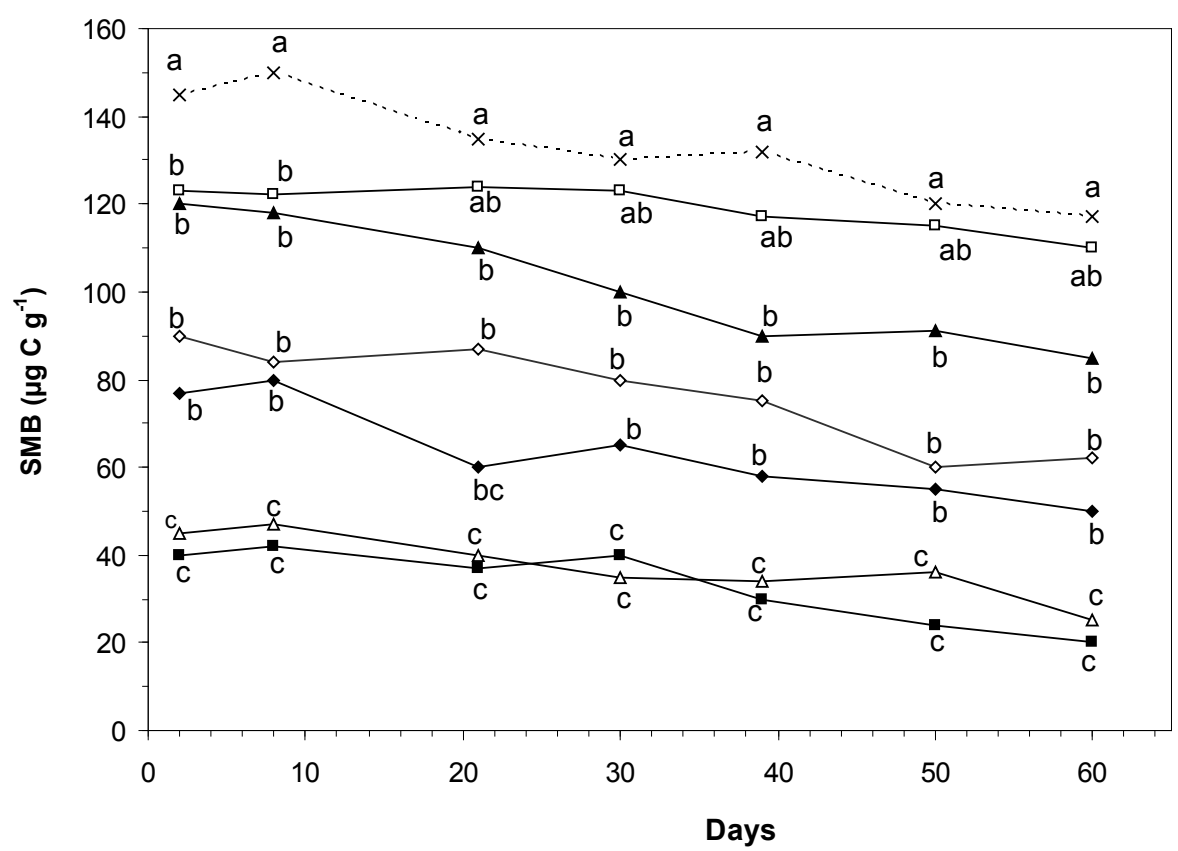

Figure 2. Soil microbial biomass (SMB) over the 60-day incubation period in a saline-sodic soil (S) under different amendments with sewage sludge (SW), mined gypsum (MG) and synthetic gypsum (SG). $\mathrm{T} 1(\Delta)=\mathrm{S}+\mathrm{MG}\left(7 \mathrm{t} \mathrm{ha}^{-1}\right) ; \mathrm{T} 2(\square)=\mathrm{S}+\mathrm{MF}\left(7 \mathrm{tha}^{-1}\right)+\mathrm{SW}\left(90 \mathrm{tha}^{-1}\right) ; \mathrm{T} 3(\bullet)=\mathrm{S}+\mathrm{SG}\left(7 \mathrm{t} \mathrm{ha}^{-1}\right) ; \mathrm{T} 4(\diamond$ )$=\mathrm{S}+\mathrm{SG}\left(7 \mathrm{tha}^{-1}\right)+\mathrm{SW}\left(90 \mathrm{tha}^{-1}\right) ; \mathrm{T} 5(\boldsymbol{\Lambda})=\mathrm{S}+\mathrm{SW}\left(90 \mathrm{t} \mathrm{ha}^{-1}\right) ; \mathrm{T} 6(\boldsymbol{\square})=\mathrm{S}+\mathrm{SW}\left(270 \mathrm{t} \mathrm{ha}^{-1}\right) ; \mathrm{T} 0(\boldsymbol{X})$ $=\mathrm{Control}$ (unamended soil). Different letters by the same day indicates a significant difference $(\mathrm{P} \leq 0.05)$. 
microbial activity, as has been similarly reported by Varnero et al. (2004). Moreover, wastes rich in potassium, such as the sewage sludge used in this study (Table 2), may improve the soil chemical properties by reducing $\mathrm{Na}^{+}$through electrostatic repulsion, in which $\mathrm{K}^{+}$replaces $\mathrm{Na}^{+}$to form potash humate (Tchouaffe, 2007).

Figure 2 shows the effect of the different amendments on SMB over the incubation period. There were significant interactions between treatments and time over the 60-day incubation period $(\mathrm{P} \leq 0.05)$. The control (T0) displayed the highest levels of SMB with time, while the sewage sludge at the highest rate (T6) and mined gypsum (T1) displayed the lowest levels of SMB. In all treatments, there was a gradual decrease of SMB over the 60-day incubation period. In our study, SMB decreased over the experimental incubation period because SMB most likely decreased the amount of available C, as also noted by Wong et al. (2008).

Table 3 shows the effects of the organic and mineral amendments on $\mathrm{M}_{\mathrm{t}} \mathrm{C}$ and $\mathrm{M}_{\mathrm{b}} \mathrm{C}$ at the end of the 60-day incubation period. $\mathrm{M}_{\mathrm{t}} \mathrm{C}$ was highest in the control (T0), whereas $\mathrm{M}_{\mathrm{b}} \mathrm{C}$ was lower in treatment $\mathrm{T} 5$. The control also showed the highest $\mathrm{M}_{\mathrm{b}} \mathrm{C}$. Clearly, the organic and mineral amendments decreased soil salinity, while the control (T0) most likely reflected a shift in population structure to one dominated by less active microorganisms, mainly fungi, with lower respiration rates compared to a population dominated by more active microorganisms, mainly bacteria
(Adu and Oades, 1978; Sadinha et al., 2003). Our results are similar to those found by Wong et al. (2008). The respiration rate was higher in the treatments with sewage sludge, indicating that OM provision decreased the levels of $\mathrm{Na}^{+}$in the saline-sodic soil, thus decreasing salinity after a 60-day incubation period. A large proportion of the OM comes from water-soluble $\mathrm{C}$, which is immediately available for microorganisms (Jandl and Sollins, 1997). In saline soils it is possible that the additional $\mathrm{OM}$ is also readily available and easily decomposable (Wong et al., 2008). Therefore, the microbial population increased due to increased nutrient supply, but as the food supply decreased, the respiration rates and SMB decreased.

Although more research is needed to evaluate the physical, chemical and biological properties of the soil, this study revealed that the saline-sodic soil was able to respond positively to large applications of sewage sludge, up to $270 \mathrm{tha}^{-1}$, which allows the possibility of recycling municipal wastes into salinity-affected soils in the northern part of Chile as part of future sustainability programs.

In conclusion, the application of sewage sludge stimulated soil microbial $\mathrm{CO}_{2}$ evolution. The highest respiration rate occurred when soil was amended with sewage sludge at the highest rate. Microbial respiration was lower when sewage sludge was mixed with gypsum before application to soil. Adding either only mined or synthetic gypsum to soil did not significantly increase

Table 3. Effects on the metabolic quotient $\left(M_{t} C\right)$ and microbial quotient $\left(M_{b} C\right)$ after 60-day incubation period in a saline-sodic soil amended with different doses of sewage sludge and gypsums.

\begin{tabular}{lcccc}
\hline Treatments & $\begin{array}{c}\mathrm{M}_{\mathrm{t}} \mathrm{C} \\
\left(\mu \mathrm{g} \mathrm{CO}_{2}-\mathrm{C} \mu \mathrm{g}^{-1} \mathrm{C}\right)\end{array}$ & $\begin{array}{c}\mathrm{M}_{\mathrm{b}} \mathrm{C} \\
(\%)\end{array}$ & $\begin{array}{c}\text { ECe } \\
(\mathrm{dS} \mathrm{m})\end{array}$ & $\begin{array}{c}\text { ESP } \\
(\%)\end{array}$ \\
\hline $\mathrm{T} 6\left(\mathrm{~S}+270 \mathrm{t} \mathrm{ha}^{-1} \mathrm{SW}\right)$ & 1.32 & 1.03 & 7.51 & 15.73 \\
$\mathrm{~T} 5\left(\mathrm{~S}+90 \mathrm{t} \mathrm{ha}^{-1} \mathrm{SW}\right)$ & 1.41 & 1.01 & 8.69 & 15.08 \\
$\mathrm{~T} 4\left(\mathrm{~S}+7 \mathrm{t} \mathrm{ha}^{-1} \mathrm{SG}\right)$ & 1.40 & 1.86 & 10.13 & 17.04 \\
$\mathrm{~T} 3\left(\mathrm{~S}+7 \mathrm{t} \mathrm{ha}^{-1} \mathrm{SG}\right)$ & 1.54 & 1.45 & 20.14 & 18.03 \\
$\mathrm{~T} 2\left(\mathrm{~S}+7 \mathrm{t} \mathrm{ha}^{-1} \mathrm{MG}+90 \mathrm{tha}^{-1} \mathrm{SW}\right)$ & 1.17 & 1.07 & 26.07 & 17.09 \\
$\mathrm{~T} 1\left(\mathrm{~S}+7 \mathrm{t} \mathrm{ha}^{-1} \mathrm{MG}\right)$ & 2.28 & 1.24 & 27.43 & 19.75 \\
T0 (unamended soil) & 3.00 & 3.56 & 100.47 & 73.68 \\
\hline
\end{tabular}

$\mathrm{S}=$ saline-sodic soil; $\mathrm{SW}=$ sewage sludge; $\mathrm{SG}=$ synthetic gypsum; $\mathrm{MG}=$ mined gypsum. 
the production of respired $\mathrm{CO}_{2}-\mathrm{C}$, most likely due to the low OM intake. The highest levels of soil microbial biomass were reached with the unamended soil over the 60-day incubation period, while the highest levels of microbial activity, measured by soil respiration, were found with high-sewage sludge amendment. This is attributed to additional substrate becoming available for the microbial population in the soil with increasing salt concentration, with the effects due to salinity more evident than those due to sodicity. This study showed that salinesodic soil responds positively when amended with large amounts of sewage sludge.

\title{
Resumen
}

\begin{abstract}
J. E. Celis, M. Sandoval, B. Martínez, y C. Quezada. 2013. Efecto de enmiendas orgánicas y minerales sobre la respiración y biomasa microbianas en un suelo salino-sódico. Cien. Inv. Agr. 40(3):571-580. El entendimiento del flujo de carbono en suelos salino-sódicos se está tornando crítico en el manejo ambiental, a medida que la salinidad y sodicidad están aumentando a nivel global. Se analizaron in vitro los efectos de lodos urbanos (SW), yeso mineral (MG) y yeso sintético (SG) en la respiración y biomasa microbiana del suelo (SMB) sobre un suelo salino-sódico $(\mathrm{S})$ por un periodo de 60 días bajo condiciones controladas. Los tratamientos fueron: $\mathrm{T} 1=\mathrm{S}+\mathrm{MG}\left(7 \mathrm{tha}^{-1}\right) ; \mathrm{T} 2=\mathrm{S}+\mathrm{MG}\left(7 \mathrm{tha}^{-1}\right)+\mathrm{SW}\left(90 \mathrm{t} \mathrm{ha}^{-1}\right) ; \mathrm{T} 3=\mathrm{S}$ $+\mathrm{SG}\left(7 \mathrm{t} \mathrm{ha}^{-1}\right) ; \mathrm{T} 4=\mathrm{S}+\mathrm{SG}\left(7 \mathrm{tha}^{-1}\right)+\mathrm{SW}\left(90 \mathrm{t} \mathrm{ha}^{-1}\right) ; \mathrm{T} 5=\mathrm{S}+\mathrm{SW}\left(90 \mathrm{t} \mathrm{ha}^{-1}\right) ; \mathrm{T} 6=\mathrm{S}+\mathrm{SW}$ $\left(270 \mathrm{t} \mathrm{ha}^{-1}\right) ; \mathrm{T} 0=\mathrm{Control}$ (suelo sin enmendar). $\mathrm{El} \mathrm{CO}_{2}$ producido por los microorganismos se determinó mediante respirometría en una cámara de incubación cerrada. SMB se midió a través del método de fumigación-extracción con cloroformo. La mayor respiración ocurrió cuando el suelo fue enmendado con T6, seguido por T5. La respiración microbiana fue la más baja cuando se aplicaron al suelo T1 y T3. Las enmiendas con yeso no aumentaron significativamente la producción de $\mathrm{CO}_{2}$ respirado debido al bajo aporte de materia orgánica (OM). Todas las enmiendas mostraron un descenso gradual de SMB en los 60 días de incubación. El suelo salino-sódico fue capaz de responder positivamente a grandes cantidades de lodo urbano enmendado a dosis de hasta $270 \mathrm{t} \mathrm{ha}^{-1}$.
\end{abstract}

Palabras clave: Actividad biológica, lodo urbano, materia orgánica, respiración del suelo, suelo árido, yeso.

\section{References}

Adu, J.K., and J.M. Oades. 1978. Utilization of organic materials in soil aggregates by bacteria and fungi. Soil. Biol. Biochem. 10:117-112.

Anderson, J.P. 1982. Soil Respiration. In: A.L. Page, R.H. Miller, and D.R. Keeney (ed.). Methods of Soil Analysis: Chemical and Microbiological Properties. American Society of Agronomy Inc, Wisconsin. p. 831-871.

Anderson, T.H., and K.H. Domsch. 1989. Ratios of microbial biomass carbon to total organic carbon in arable soils. Soil Biol. Biochem. 21: 471-479.
Anderson, T.H., and K.H. Domsch. 1993. The metabolic quotient for $\mathrm{CO}_{2}\left(\mathrm{qCO}_{2}\right)$ as a specific activity parameter to assess the effects of environmental conditions, such as $\mathrm{pH}$ on the microbial biomass of forest soils. Soil Biol. Biochem. 25: 393-395.

Arshad, M.A. 2008. Soil Salinity and Salinization. In: W. Chesworth (ed.). Encyclopedia of Soil Science. Springer, Dordrecht, The Netherlands. p. 699-703.

Avnimelech, Y., D. Shkedy, M. Kochba, and Y. Yotal. 1994. The use of compost for the reclamation of saline and alkaline soils. Compost Sci. Util. 2: 6-11. 
Aydemir, S., and N.F. Najjar. 2005. Application of two amendments (gypsum and langbeinite) to reclaim sodic soil using sodic irrigation water. Aust. J. Soil Res. 43: 547-553.

Banerjee, M.R., D.L. Burton, and S. Depoe. 1997. Impact of sewage sludge application on soil biological characteristics. Agr. Ecosyst. Environ. 66: 241-249.

Barrena, R., F. Vázquez, and A. Sánchez. 2006. The use of respiration indices in the composting process: a review. Waste Manage. Res. 24: 37-47.

Bell, D.T. 1999. Australian trees for the rehabilitation of waterlogged and salinity damaged landscapes. Aust. J. Bot. 47: 697-716.

Celis, J.E., M.A. Sandoval, and N. Bello. 2011. Nolinear respiration dynamics in a degraded alfisol amended with different dose of salmon sludges. J. Soil Sci. Plant Nutr. 11: $58-67$.

Celis, J., M. Sandoval, and E. Zagal. 2009. Actividad respiratoria de microorganismos en un suelo patagónico enmendado con lodos salmonícolas. Arch. Med. Vet. 41: 277-281.

Clark, R.B., K.D. Ritchey, and V.C. Baligar. 1999. Benefits and constraints for use of FGD products on agricultural land. Fuel 80: 821-828.

DeSutter, T., and J. Cihacek. 2009. Potential agricultural uses of flue gas desulphurization gypsum in the northern great plains. Agron. J. 101: 817-825.

Esparza, J., M. Diez, M., and F. Gallardo. 2004. Aplicación de Lodos de la Industria de Celulosa a Suelos Andisoles Chilenos. In: M. Mora (ed.). Simposio Residuos Orgánicos y su Uso en Sistemas Agroforestales. Universidad de la Frontera, Temuco, Chile. p. 27-38.

Fekete, J., and O. Feher. 2000. The Results of Amelioration of Sodic and Alkaline Soils. In: J.L. Rubio, R. Morgan, S. Asins, and V. Andreu (ed.). Man and Soil at the Third Millennium: Proceedings of the International Congress of the European Society for Soil Conservation. University of Valencia. Valencia, Spain. p. 1525-1533.

Ianotti, D., T. Pang, and B. Toth. 1994. A quantitative respirometric method for monitoring compost stability. Compost Sci. Utiliz. 1: 52-65.

Jandl, R., and P. Sollins. 1997. Water-extractable soil carbon in relation to the below-ground carbon cycle. Biol Fertil Soils 25: 196-201.
Kochba, M., G. Ritvo, and Y. Avnimelech. 2004. The effect of municipal solid waste compost (MSW) on the replacement of sodium in sodic soil models. Soil Sci. 169: 567-572.

López-Aguirre, J.G., J. Farias-Larios, J. MolinaOchoa, S. Aguilar-Espinosa, M. Flores-Bello, and M., González-Ramírez. 2007. Salt leaching process in an alkaline soil treated with elemental sulphur under dry tropic conditions. World J. Agr. Sci. 3: 356-362.

Muhammad, S., T. Muller, and R. Joergensen. 2008. Relationship between soil biological and other soil properties in saline and alkaline arable soils from the Pakistani Punjab. J. Arid Envir. 72: 448457.

Muneer, W., and J.M. Oades. 1989. The role of Caorganic interactions in soil aggregate stability. III. Mechanisms and models. Aust. J. Soil Res. 27: 411-423.

Nelson, P., B. Rahman, and J. Oades. 1997. Sodicity and clay type: influence on decomposition of added organic matter. Soil Sci. Soc. Amer. J. 61: 1052-1057.

Oren, A. 1999. Bioenergetic aspects of halophilism. Microbiol. Molec. Biol. Rev. 65: 334-348.

Parton, W., D. Schimel, C. Cole, and D. Ojima. 1987. Analysis of factors controlling soil organic matter levels in great plains grasslands. Soil Sci. Soc. Am. J. 51: 1173-1179.

Pascual, J., C. García, and T. Hernández. 1999. Lasting microbiological and biochemical effects of the addition of municipal solid waste to an arid soil. Biol. Fertil. Soils 30: 1-6.

Pathak, H., and D. Rao. 1998. Carbon and nitrogen mineralization from added organic matter in saline and alkali soils. Soil Biol. Biochem. 30: 695-702.

Rietz, D.N., and R.J. Haynes. 2003. Effect of irrigation-induced salinity and sodicity on soil microbial activity. Soil Biol. Biochem. 35: 845-854.

Ros, M., M. Hernández, and C. García. 2003. Soil microbial activity after restoration of a semiarid soil by organic amendments. Soil Biol. Biochem. 35: 463-469.

Sadinha, M., T. Muller, H. Schmeisky, and R.G. Joergensen. 2003. Microbial performance in soils 
along a salinity gradient under acidic conditions. Appl. Soil Ecol. 23:237-244.

Santibáñez, F., and A. García. 2000. Suelos. In: Informe País, Estado del Medio Ambiente en Chile. Universidad de Chile, LOM Ediciones. Santiago, Chile. p. 203-244.

Saviozzi, A., R. Riffaldi, R. Levi-Minzi, A. Scagnozzi, and G. Vanni. 1993. Decomposition of vegetation-water sludge in soil. Bioresour. Technol. 44: 223-228.

Shah, S., and Z. Shah. 2011. Changes in soil microbial characteristics with elevated salinity. Sarhad J. Agric. 27: 233-244.

Tchouaffe, N.F. 2007. Strategies to reduce the impact of salt on crops (rice, cotton and chilli) production: a case study of the tsunami-affected area of India. Desalination 206: 524-530.

Thomas, D.S., and N.J. Middleton. 1993. Salinization: new perspectives on a major desertification issue. J. Arid Environ. 24: 95-105.

Tripathi, S., S. Kumari, A. Chakraborty, A. Gupta, K. Chakrabarti, and B. Bandyapadhyay. 2006. Microbial biomass and its activities in salt-affected coastal soils. Biol. Fertil Soils 42: 273-277.

Vance, W.H., P.C. Brookes, and D.J. Jenkinson. 1987. An extraction method for measuring soil microbial biomass C. Soil Biol. Biochem. 19: 703-707.

Varnero, M.T., P. Faúndez, C. Santibáñez, and P. Alvarado. 2004. Evaluación de Lodo Fresco y Compostado como Materia Prima para la Elaboración de Sustratos. In: M. Mora (ed.). Simposio Residuos Orgánicos y su Uso en Sistemas Agroforestales. Universidad de la Frontera, Temuco, Chile. p. 477-481.

Vukadinovic, V., and Z. Rengel. 2007. Dynamics of sodium in saline and sodic soils. Commun. Soil Sci. Plan. 38: 2077-2090.

Wong, V., R. Dalal, and R. Greene. 2008. Salinity and sodicity effects on respiration and microbial biomass of soil. Biol. Fertil. Soils 44: 943-953.

Yunlong, C., and B. Smit. 1994. Sustainability in agriculture: a general review. Agric. Ecosyst. Environ. 49: 299-307.

Zagal, E., N. Rodríguez, I. Vidal, and L. Quezada. 2002. Actividad microbiana en un suelo de origen volcánico bajo distinto manejo agronómico. Agric. Téc. (Chile) 62: 297-309.

Zahran, H.H. 1997. Diversity, adaptation and activity of the bacterial flora in saline environments. Biol. Fertil. Soils 25: 211-223. 